УДК 339.5

\title{
ІМПЛЕМЕНТАЦІЯ ДОСВІДУ ЗАРУБІЖНИХ КРАЇН В УКРАЇНСЬКУ ПРАКТИКУ МИТНОГО КОНТРОЛЮ
}

\section{IMPLEMENTATION OF THE EXPERIENCE OF FOREIGN COUNTRIES IN THE UKRAINIAN PRACTICE OF CUSTOMS CONTROL}

\author{
Гуцул Інна Анатоліївна \\ кандидат економічних наук, доцент, \\ Західноукраїнський національний університет \\ ORCID: https://orcid.org/0000-0003-2281-5940
}

\author{
Hutsul Inna \\ West Ukrainian National University
}

\begin{abstract}
У статті досліджено актуальні аспекти митної політики деяких зарубіжних країн в контексті здійснення митного контролю. Значну увагу приділено інформаційному та сервісному забезпеченню контрольної діяльності митних адміністрацій. Досліджено досвід країн Європейського Союзу, який підтвердив пріоритетність діджиталізації митної справи в Україні. Висвітлено стратегічні цілі діяльності литовських митних органів у сорері протидії митним правопорушенням та відпрацюванні фріскальних ризиків. Встановлено, що митні інституції США, Франції, Японії та Болгарії активно використовують механізми митного пост-аудиту, що дозволяє краще виконувати поставленні перед митними органами завдання. Ірландська система митного контролю пропагує електронні сервіси та акцентується на підвищенні сумлінності декларування та сплати митних платежів. Систематизовано шляхи удосконалення контрольної діяльності митних органів в Україні з урахуванням адекватного зарубіжного досвіду.

Ключові слова: фріскальна політика, митний контроль, митний пост-аудит, митний ризик, контрабанда, митні органи зарубіжних країн.
\end{abstract}

В статье исследованы актуальные аспекты таможенной политики некоторых зарубежных стран в контексте осуществления таможенного контроля. Значительное внимание уделено информационному и сервисному обеспечению контрольной деятельности таможенных администраций. Исследован опыт стран Европейского Союза, который подтвердил приоритетность диджитализации таможенного дела в Украине. Освещены стратегические цели деятельности литовских таможенных органов в сфрере противодействия таможенным правонарушениям и отработки фискальных рисков. Установлено, что таможенные учреждения США, Франции, Японии и Болгарии активно используют механизмы таможенного пост-аудита, что позволяет лучше выполнять поставленные перед таможенными органами задания. Ирландская система таможенного контроля пропагандирует электронные сервисы и акцентируется на повышении добросовестности декларирования и уплаты таможенных платежей. Систематизированы пути совершенствования контрольной деятельности таможенных органов в Украине с учетом адекватного зарубежного опыта.

Ключевые слова: фрискальная политика, таможенный контроль, таможенный пост-аудит, таможенный риск, контрабанда, таможенные органы зарубежных стран.

The article examines current aspects of customs policy of some foreign countries in the context of customs control. Considerable attention is paid to information and service support of control activities of customs administrations. The experience of the European Union countries, which confirmed the priority of digitalization of customs in Ukraine, is studied. European integration processes in Ukraine necessitate the restructuring of the customs control system in the direction of its simplification and harmonization. It is stated that the study of the effectiveness of customs control as an important function of customs authorities requires consideration of a number of aspects of scientific and applied nature of developed countries. The strategic goals of the Lithuanian customs authorities in the field of combating customs offenses and working out fiscal risks are highlighted. It is established that the customs institutions of the USA, France, Japan and Bulgaria actively use the mechanisms of customs post-audit, which allows to better perform the tasks set before the customs authorities. With the help of customs post-audit, you can identify schemes that are used to evade taxes and customs duties. The Irish customs control system promotes electronic services and focuses 
on improving the honesty of the declaration and payment of customs duties. The application of the French model of customs control requires a high level of organization of information and analytical support and a sufficient number of highly qualified specialists. Ways to improve the control activities of customs authorities in Ukraine are systematized, taking into account adequate foreign experience. Among them are the following: introduction and functioning of the Institute of Authorized Economic Operator; use of the principles of complexity and selectivity of customs control at all stages of the supply chain; improvement of the customs risk management system; improvement of customs infrastructure and software and hardware of customs authorities; innovation in the technical means of customs control; increasing the level of motivation and professional competence of employees of fiscal institutions.

Keywords: fiscal policy, customs control, customs post-audit, customs risk, smuggling, customs authorities of foreign countries.

Постановка проблеми. Процес глобалізації як механізм стимулюючого розвитку світового господарства $є$ пріоритетним фрактором подальшого прискорення транскордонної співпраці та торгівлі. Бажання України стати членом європейської спільноти стає додатковим потужним стимулом соціальноекономічних перетворень, в реалізації яких важлива роль належить міжнародному співробітництву, що здійснюється в галузі державної митної справи. Націлення України на євроінтеграційні процеси та лібералізацію зовнішньоекономічної діяльності виступає важливим завданням сьогодення в контексті розвитку вітчизняної економіки. Одну з ключових ролей в цій площині відіграє ефрективне здійснення митного контролю. Динамізм цифрової трансорормації вимагає від органів Державної митної служби України імплементації кращої світової практики в сорері митного офрормлення та контролю, а також управління митними ризиками. Зазначене обумовлює актуальність проведення даного наукового дослідження.

Аналіз останніх досліджень і публікацій. Проблематику фіскальної політики, митного контролю та митного пост-аудиту дослідили у своїх науково-методичних роботах такі вчені та практики як Адамів М.є., Андрушко А.П., Вакульчик О.М., Десятнюк О.М., Єдинак В.Ю., Єдинак Т.С., Івашова Л.М., Калуга Н.В., Караваєв Т.А., Корнійчук Н.І., Мельник О.Г., Мережко Н.В., Очерет А.Ю., Попук Н.С., Саварець А.В., Тодощук А.В., Фабіянська В.Ю., Харкавий М.О. та інші.

Виділення невирішених раніше частин загальної проблеми. Дослідження ефрективності митного контролю як важливої фрункції митних органів потребує врахування низки аспектів науково-прикладного характеру. По перше, важливо дослідити прагматизм його здійснення в зарубіжних країнах в ракурсах цифрровізації та глобального співробітництва. По друге, варто зробити акценти на потенціалі митного контролю в контексті протидії фріс- кальним правопорушенням та контрабандним явищам. По третє, системність технічних, технологічних, інфрормаційних, сервісних, кадрових, інноваційних та інших чинників митного контролю має трансорормуватися у фріскальні та соціальні ефекти.

Формулювання цілей статті. Мета роботи - дослідження актуальних тенденцій митного контролю в зарубіжних країнах та окреслення ключових аспектів його імплементації в український прагматизм.

Виклад основного матеріалу дослідження. Митний контроль виступає одним 3 ключових завдань, які стоять перед митними органами кожної країни. Економічна та фріскальна безпека держави перманентно залежить від митного контролю, тому що на цьому етапі відбувається не тільки перевірка всіх митних (вантажних) документів, а й безпосереднє встановлення кількісних та якісних показників товарів, які переміщуються через митний кордон України.

Основним підґрунтям сучасних процедур митного контролю $€$ використання інфрормаційних технологій. Тенденції світового розвитку встановлюють нові завдання щодо спрощення митних процедур при здійсненні експортно-імпортних операцій, для чого створюються електронні інфрормаційні системи, функціонально сумісні між аналогічними системами різних країн, доступні, керовані, безпечні, об'єднані та контрольовані. Застосування інсрормаційних технологій дозволяє не лише високоякісно й ефективно працювати в сучасному глобалізованому світі, але й заощаджувати час і ресурси та збільшувати прибутки [1, с. 7]. Таким чином, провідні митні адміністрації в різних країнах світу активно переходять на електронні технології. Зокрема, держави-члени $Є С$ прийняли рішення діяти в рамках структури «Електронна митниця» (e-Customs), тобто простого і безпаперового середовища фрункціонування митних адміністрацій та суб'єктів зовнішньоекономічної діяльності. 
Сучасна парадигма здійснення митної політики держави у напрямі спрощення митних процедур щодо міжнародних товаропотоків окреслила найважливіший принцип митного контролю - принцип вибірковості, який означає, що немає потреби проводити контроль у повному обсязі, тобто перевірку всіх товарів. Цей принцип має «демократичне та альтернативне підґрунтя» і корелюється 3 основними положеннями Кіотської конвенції, а фоорма митного контролю обирається на підставі результатів автоматизованої системи аналізу та управління ризиками, тобто шляхом перевірки електронної копії митної декларації в автоматизованому режимі з використанням сукупності програмно-інформаційних комплексів [2].

В умовах поглиблення торгових взаємовідносин між країнами державні митні органи практично всіх держав мають вирішувати проблему щодо дотримання певного балансу між дієвою й ефективною системою митного контролю та оперативного реагування на виникнення небезпечних ситуацій під час митного оформлення, а також полегшенням загальної ситуації для учасників зовнішньоекономічної діяльності. Євроінтеграційні процеси в Україні обумовлюють необхідність перебудови вітчизняної системи митного контролю у напрямку його діджиталізації, спрощення та гармонізації.

Розглядаючи основні аспекти роботи митних органів Литовської Республіки, констатуємо, що вона реалізовується відповідно до Стратегії розвитку литовської митниці на певний період (зокрема на 2016-2020рр.). Місія литовської митниці полягає у фрормуванні та підтриманні законної, безпечної, чесної та безперебійної міжнародної торгівлі. Основною метою діяльності митних органів Литви є фрормування надійного захисту суспільства, ринку, навколишнього середовища, а також фрінансових інтересів Литовської Республіки та ЄС у ссрері міжнародної торгівлі, впровадження митної політики ЄС, партнерської торгівлі та інших спільних політик Союзу, пов'язаних із зовнішньою торгівлею. Поряд 3 цим, митні установи Литви орієнтуються та такі цінності, як: повага до кожної особи (фрізичної та юридичної) і держави; профресіоналізм; партнерство. Водночас, довгострокові стратегічні цілі литовської митниці трансфрормуються через забезпечення оптимальної реалізації митних процедур, посиленням боротьби із незаконною міжнародною торгівлею, контрабандою, митними деліктами та загрозами національній і міжнародній безпеці [3].
При здійсненні контролю за міжнародною торгівлею в межах $€ С$, митниця Литви сприяє формуванню чесної та відкритої торгівлі, захисту внутрішнього ринку Литовської Республіки, безпеки усього ланцюга постачання. У активній співпраці з іншими органами влади митні інституції Литви відіграють основну роль у забезпеченні законної торгівлі та підвищенні конкурентоспроможності держави і ЄС; належного оподаткування суб'єктів зовнішньоекономічної діяльності; протидії різним схемам шахрайства, організованою злочинністю, незаконним переміщенням наркотичних речовин та тероризмом шляхом якісного оброблення інсрормації, ідентиорікації змін у моделях торгівлі та моніторингу ризиків для виявлення фрінансових махінацій, терористичних і злочинних дій; захисті навколишнього природнього середовища та населення від різного роду небезпечної продукції [4, с. 8]. Митно-прикордонна служба США (U.S. Customs \& Border protection) - одне 3 агентств, що входить до складу Міністерства внутрішньої безпеки США - U.S. Department of Homeland Security, яке включає в себе 21 профрільне відомство. До основних фрункцій Митно-прикордонної служби США відносяться наступні: правоохоронна, що передбачає боротьбу з тероризмом та незаконною міграцією, захист національної економіки, захист довкілля і здоров'я громадян, збереження культурної спадщини, охорона державного кордону, а також підтримка законної зовнішньої торгівлі та туризму [5, с. 4].

У Франції фрункціонує ступенева система здійснення митного контролю, яка інтерпретується наступними рівнями:

1) фрормальний - суцільний аудит достовірності офрормлення та наявності всіх необхідних документів і реквізитів;

2) фрундаментальний - вибірковий аудит відповідності виду, номенклатури, вартості та походження товарів поданим документам, перевірка обґрунтованості наявних пільг тощо.

Цікавим $€$ той фракт, що фрормальний митний контроль здійснюється або спеціальними аудиторсько-аналітичними службами за допомогою поглибленої документальної перевірки без виїзду на підприємство, або митними аудиторами особисто на підприємстві. До позитивних ефеектів такої організації митного контролю доцільно віднести наступні: фрорсування митного офрормлення вантажів під час перетину митного кордону; зростання ймовірності виявлення порушень митного законодавства та контрабандних поставок, оскільки 
постає можливість перевірки правильності заявленого в декларації обсягу та призначення вантажу. Однак, імплементація фрранцузької моделі митного контролю потребує як підвищеного рівня інформаційно-аналітичного забезпечення, так і достатньої кількості висококваліфрікованих фрахівців у галузі митного контролю та аудиту [6, с. 26].

Митний пост-аудит ідентифрікується як ефективна фоорма митного контролю, що допускає використання різних аналітичних процедур, агломерацію фрорм митного контролю, які дають перспективу краще виконувати поставленні перед митними органами завдання. Митний пост-аудит виступає однією із новітніх форм митного контролю у розвинених країнах світу та забезпечує більше 30\% усіх митних платежів.

Митні інститути Болгарії для ідентифікації достовірності даних митної декларації володіють правом після випуску товарів здійснювати наступний контроль відповідних документів і даних про операції з імпорту та експорту задекларованих товарів. Вказаний контроль здійснюється посадовими особами регіональних митних органів під час виїзної або невиїзної документальної перевірки. В цьому аспекті об'єктом перевірки виступають товари, бухгалтерські книги, торгова, облікова та інша документація підприємства, що перевіряється. Варто констатувати, що у митній службі Болгарії нормативний документ, що регламентує саму процедуру проведення митного пост-аудиту, називається «Керівництво для здійснення митного пост-аудиту». Він розпочинається 3 визначення мети та основних детермінант митного пост-аудиту. Значна увага приділена попередньому аудиту і графріку проведення аудиторських перевірок. Водночас, описується система аналізу й оцінки ризиків, що є невід'ємним компонентом митного аудиту. У зазначеному документі прописано методику проведення перевірки та відображено організаційну схему здійснення пост-аудиту (вид, обсяг, часові нормативи та деталізовані стадії) [7, с. 216].

У структурі центрального апарату митної служби Японії фрункціонує Департамент постаудиту, розслідування та розвідки, який виконує такі контрольні завдання: дослідження та складання запитів, що стосуються цінностей, вантажів, страхування імпортних товарів для застосування відповідних ставок імпортного тарифр; розслідування порушень митних правил, а також збір та аналіз інформації про митно-фрінансові порушення; співпраця з митними адміністраціями зарубіжних країн вна- слідок обміну інфрормацією про порушення митного законодавства; складання і декламація статистики зовнішньої торгівлі та іншої необхідної інфрормації [8, с. 47-48].

Цікавим фрактором у досвіді Ірландії $€$ те, що контрольно-перевірочні завдання в митній сорері виконує Відомство доходів Ірландії. Пріоритет надається не фріскальній фрункції, а контролюючій та профрілактичній, які більше націлюються на інформування та підвищення свідомого рівня дотримання суб'єктами ЗЕД законодавства, прозорість декларування результатів їхньої діяльності. Поряд 3 цим, головною метою уряду Ірландії залишається заохочувати мешканців до добровільної сплати податкових і митних платежів та недопускання помилок, які вони можу зробити.

В Ірландії митно-податковий аудит здійснюється у формі неаудиторського втручання та має такі підвиди: профрільні інтерв'ю (у формі опитування суб'єктів ЗЕД); направлення запитів; фрактичний контроль за реєстраторами розрахункових операцій; галузеві огляди; отримання та моніторинг інформації 3 інших державних і приватних організацій; відвідування інтернет-сайтів суб'єктів підприємництва тощо.

Значну роль відносять електронному митному аудиту, що базується на перевірці достовірних даних за допомогою баз інформаційних комп'ютерних програм і електронних копій документів, які суб'єкти ЗЕД подають при запиті контролюючому органу [9, с. 67].

На нашу думку, за допомогою митного пост-аудиту можливо ідентифікувати схеми, які використовують для ухилення від сплати податкових і митних платежів, що відбуваються на регулярній основі, а також сорормувати відповідні критерії ризиків для пошуку порушень митного законодавства. Таким чином, пріоритетним на сьогодні для митних органів в Україні $є$ повноцінна апробація системи пост-митного аудиту, що дозволить значно прискорити офрормлення і випуск товарів у вільний обіг [10, с. 221], а також запобігти втратам державного бюджету, покращити рівень адміністрування митних платежів, гарантувати захист внутрішнього ринку від недобросовісної конкуренції при імпорті товарів.

Висновки. В умовах євроінтеграційних процесів пріоритети у здійсненні державної митної політики безпосередньо пов'язані з підвищенням ефективності митного контролю та офрормлення товарів шляхом спрощення митних процедур, упровадження інфрормаційних технологій, розширення співпраці «митницябізнес», подальше удосконалення функціо- 
налу «е-Customs», інтенсифрікація використання Смарт-митниці. Поряд із цим, базуючись на зарубіжному досвіді організації та здійснення митного контролю (аудиту) слід виділити певні рекомендації для української практики. Зокрема, мова йде про наступні заходи:

- виконання норм Митного кодексу України з приводу фрормування та фрункціонування Інституту уповноваженого економічного оператора. Закцентуємо, що серед країн ЄС надання статусу уповноваженого економічного оператора здійснюється пропорційно до економічного розвитку держави. У Німеччині видається близько 25\% від усіх наданих сертифрікатів у $€ C$, у Нідерландах - $15 \%$, у Швеції - 10\%, у Франції - 9\%, у Італії - 8\%, у Великобританії $7 \%$ [11, с. 10]. Такий статус надається підприємству лише після проведення митними органами ретельної перевірки його діяльності;

- практична агломерація принципів комплексності та вибірковості митного контролю на усіх етапах ланцюга постачання. Це дозволить підвищити рівень виявлення митних пра- вопорушень та, водночас, пришвидшити реалізацію митних процедур;

- систематичне вдосконалення системи управління митними ризиками;

- покращення інфрормаційно-аналітичної роботи митних органів на базі співпраці 3 іншими національними та міжнародними контролюючими органами з ціллю оперативного реагування і протидії митним деліктам;

- активізація розвитку митної системи України на за садах масштабного удосконалення митної інсрраструктури та програмно-технічного забезпечення роботи митних органів;

- інноватизація технічних засобів митного контролю та активізація залучення кінологічних команд органами ДМС України;

- підвищення рівня мотивації та срахової компетентності працівників митно-податкових органів. Це продукуватиме зниження корупційних явищ;

- гармонізація митного законодавства в сорері контролю та управління ризиками 3 нормативами розвинених країн світу тощо.

\section{СПИСОК ВИКОРИСТАНИХ ДЖЕРЕЛ:}

1. Мережко Н., Караваєв Т., Калуга Н. Подолання бар'єрів у міжнародній торгівлі через спрощення митних процедур. Зовнішня торгівля: економіка, фрінанси, право. 2018. № 3. С. 5-20.

2. Десятнюк О. М., Харкавий М. О. Новітня парадигма реалізації митного контролю в умовах спрощення митних процедур. Ефрективна економіка. 2015. № 3. URL: http://nbuv.gov.ua/UJRN/efek_2015_3_4

3. Офіційний сайт митниці Литовської Республіки. URL: http://www.Irmuitine

4. Мельник О.Г., Адамів М.Є., Тодощук А.В. Митний досвід Литовської Республіки: особливості імплементації в Україні. Інвестиції: практика та досвід. 2018. № 20. С. 5-9.

5. Саварець А.В. Український та зарубіжний досвід побудови митних органів: рекомендації для сучасної України : консультативна робота. Київ : ГО «ІЕДПК», 2017. 24 с.

6. Івашова Л.М., Єдинак Т.С., Єдинак В.Ю. Основи митного пост-аудиту : навч. посібник. Дніпропетровськ : АМСУ, 2011. 200 C.

7. Андрушко А.П. Імплементація іноземного досвіду здійснення митного постаудиту в Україні: проблеми та перспективи. Публічне управління та митне адміністрування. 2017. № 2(17). С. 214-219.

8. Формування системи митного аудиту в Україні : монографрія / за заг. ред. О.М. Вакульчик. Хмельницький : ПП Мельник А.А., 2014. 208 с.

9. Корнійчук Н.І. Проблеми та напрями вдосконалення митного контролю і митного аудиту. Економіка та митно-правові відносини. 2019. Вип. 9-10. С. 64-70.

10. Фабіянська В.Ю., Попук Н.С. Економічна ефективність пост-аудиту. Економічний аналіз. 2015. T. 19(1). C. 218-223.

11. Мережко Н., Калуга Н., Очерет А. Інститут уповноваженого економічного оператора в Україні. Зовнішня торгівля: економіка, фрінанси, право. 2016. № 2. С. 5-14.

\section{REFERENCES:}

1. Merezhko N., Karavaiev T., Kaluha N. (2018) Podolannia barieriv u mizhnarodnii torhivli cherez sproshchennia mytnykh protsedur [Overcoming barriers in international trade through simplification of customs procedures]. Zovnishnia torhivlia: ekonomika, finansy, pravo, no. 3, pp. 5-20.

2. Desiatniuk O. M., Kharkavyi M. O. (2015) Novitnia paradyhma realizatsii mytnoho kontroliu v umovakh sproshchennia mytnykh protsedur [The modern paradigm of customs control in terms of simplification of customs procedures]. Efektyvna ekonomika, no. 3. URL: http://nbuv.gov.ua/UJRN/efek_2015_3_4 
3. Ofitsiinyi sait mytnytsi Lytovskoi Respubliky [Official website of the Customs of the Republic of Lithuania]. URL: http://www.Irmuitine

4. Melnyk O.H., Adamiv M.le., Todoshchuk A.V. (2018) Mytnyi dosvid Lytovskoi Respubliky: osoblyvosti implementatsii v Ukraini [Customs experience of the Republic of Lithuania: features of implementation in Ukraine]. Investytsii: praktyka ta dosvid, no. 20, pp. 5-9.

5. Savarets A.V. (2017) Ukrainskyi ta zarubizhnyi dosvid pobudovy mytnykh orhaniv: rekomendatsii dlia suchasnoi Ukrainy [Ukrainian and foreign experience in building customs authorities: recommendations for modern Ukraine]. Kyiv: HO «IEDPK», 24 p.

6. Ivashova L.M., Yedynak T.S., Yedynak V.lu. (2011) Osnovy mytnoho post-audytu [Fundamentals of customs post-audit]. Dnipropetrovsk: AMSU, 200 p.

7. Andrushko A.P. (2017) Implementatsiia inozemnoho dosvidu zdiisnennia mytnoho postaudytu v Ukraini: problemy ta perspektyvy [Implementation of foreign experience in customs post-audit in Ukraine: problems and prospects]. Publichne upravlinnia ta mytne administruvannia, no. 2(17), pp. 214-219.

8. Vakulchyk O.M. (2014) Formuvannia systemy mytnoho audytu v Ukraini [Formation of the customs audit system in Ukraine]. Khmelnytskyi: PP Melnyk A.A., 208 p.

9. Korniichuk N.I. (2019) Problemy ta napriamy vdoskonalennia mytnoho kontroliu i mytnoho audytu [Problems and directions of improvement of customs control and customs audit]. Ekonomika ta mytno-pravovi vidnosyny, no. 9-10, pp. 64-70.

10. Fabiianska V.Iu., Popuk N.S. (2015) Ekonomichna efektyvnist post-audytu [Economic efficiency of postaudit]. Ekonomichnyi analiz, no. 19, pp. 218-223.

11. Merezhko N., Kaluha N., Ocheret A. (2016) Instytut upovnovazhenoho ekonomichnoho operatora v Ukraini [Institute of Authorized Economic Operator in Ukraine]. Zovnishnia torhivlia: ekonomika, finansy, pravo, no. 2, pp. 5-14. 